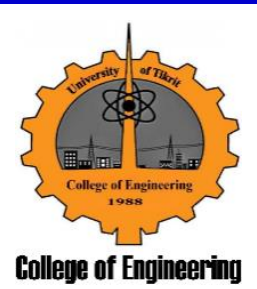

ISSN: 1813-162X (Print) ; 2312-7589 (Online)

\title{
Tikrit Journal of Engineering Sciences
}

available online at: http://www.tj-es.com

\section{TJES \\ Tikrit Journal of \\ Engineering Seienters}

Al-Flaiyeh MA, Aziz NH. Enhancement Stability of the Power System Using Static Synchronous Compensators Connected in Different Formats. Tikrit Journal of Engineering Sciences 2021; 28(1): 1- 12.

Maha Abdulrhman Al-Flaiyeh*

Nagham Hikmat Aziz

Electrical Department/ Engineering College/Mosul University / Mosul, Iraq

\section{Keywords:}

Critical-Clearing-Time (CCT)

,STATCOM, FACTs compensator

,Stability voltage control.

\section{A R T I C L E I N F O}

\section{Article history:}

Received $\quad 17$ Jun. 2020

Accepted 22 July 2020

Available online 09 May 2021

\section{Enhancement Stability of the Power System Using Static Synchronous compensators Connected in Different Formats}

\author{
A B S T R A C T
}

The research strategy focuses on the effect of connecting a STATCOM to mend critical-clearing-time (CCT) for the studied system and its transient stability. This paper targets to connect STATCOM in two situations, grouped and distributed. The first situation connects STATCOM at one placement with 100 MVAR reactive power while the second situation connects two STATCOMs at two different placements with the value 50 MVAR for each one and 60 MVAR,40 MVAR in another case. It has been found through this research that when distributing the necessary compensation capacity to more than one static synchronous compensator better than from combined them in one compensator in improving the CCT. It used MATLAB / ver.2017 for simulation of our studied system (IEEE-9 nodes).

(C) 2021 TJES, College of Engineering, Tikrit University

OI: http://doi.org/10.25130/tjes.28.1.01

تعزيز استقرار نظام القدرة باستخدام معوضات تزامنية ساكنة تربط بتنسيقات مختلفة

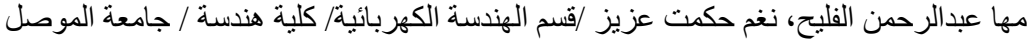
الخلاصنه

تركز استر اتيجية البحث على تأثير ربط STATCOM لتحسين زمن الاز الة الحرج للنظام المدروس و استقر اريته العابرة. تهدف هذه الورقة إلى ربط الـ

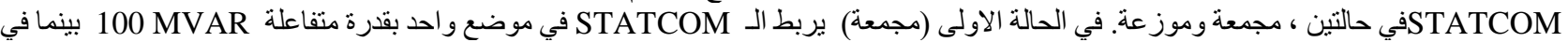
الحالة الثانية (موز عة) يربط اثنان من الـ STATCOMs في موضعين مختلفين بقيمة

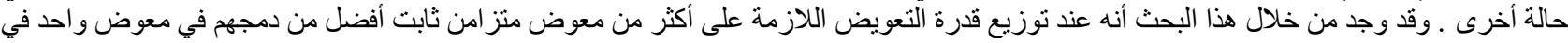

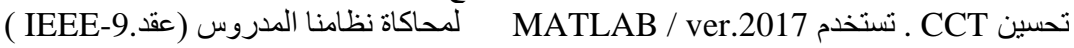

\section{INTRODUCTION}

\footnotetext{
${ }^{*}$ Corresponding Author: Maha Abdulrhman Al-Flaiyeh
} 
Earlier main operating requirements of an A.C power system (PS) are that the synchronous generators must remain in synchronism and the voltages must be kept close to their rated values [1]. the ability of the system to meet these requirements when exposed to disturbances is called a dynamic response.

As a consequence of increasing power demand, some transmission lines are more loaded than was planned when it was designed the increased loading of long transmission lines, and the possibility of fault in the system, a problem of transient stability will emerge. The resulting system response involves a large deviation of generator rotor angles, where stability depends upon both the initial operating conditions of the system and the severity of the disturbance. so the recent development of power electronics introduces the use of a flexible A.C transmission system (FACTS) to treat this problem.[2]

In many studies, it was found that the STATCOM is provided to the electric grid when It is placed at the midpoint between the two generating centers a maximum advantages of stabilization voltages as well as support transmitted power on transmission lines while other research has shown that the STATCOM gives better advantages than normal when it is positioned in the middle of the line when it is somewhat far from the middle of the line towards sending point.[1][3]

Other researchers in the same field have also concluded that the ideal location for the STATCOM at the receiving end near the load is the most affected system contract by the Changes in tension and therefore this effect is reflected in the stability of the electrical networks It supports transmitted power lines thus support any stabilization of the electrical system[1].Researchers in [4] uses energy function to model a simple power system equipped with a STATCOM in order to determine the critical clearing time of the system; it is shown the STATCOM enhances the transient stability of single machine infinite bus system. Authors in [5] propose three schemes including the installation of power factor correction capacitor, Static Var Compensator (SVC) and STATCOM for the enhancement of grid-disconnection operation for a cogeneration plant. [6] looks at the use of transient stability and CCT to properly locate STATCOM and series compensator working independently as well as simultaneously in a multi-machine power system. In stability respect, the (CCT) is a very important value of power system (PS). It is the maximum period of time that the PS can withstand when a malfunction occurs and remove it without losing its stability. Consequently, increasing CCT is one of the main priorities for increasing system stability.

In this paper, STATCOM is connected in many ways grouped and distributed and at various locations to improve CCT in a multi-machine (IEEE-9bus). This system is modeled in Matlab 2017/Simulink. The critical clearing time for system without or with STATCOM was determined by simulating faults on the transmission lines and cleared the faults using try and error method .The STATCOM and principal work of it describe in sections 2 and 3 . The test system presentation and discussion of the results are given in sections 4 and 5 .The paper's conclusions are presented in section 6 .

\section{STATIC SYNCHRONOUS COMPENSATOR (STATCOM):}

STATCOM is one of the key FACTS devices. Based on a voltage-sourced- converter, the STATCOM regulates system voltage by absorbing or generating reactive power.[7][8]

A STATCOM can supply the required reactive power under different operating conditions, to control the network voltage actively and thus, improve the steadystate stability of the network. The STATCOM can be operated over its full output current range even at very low voltage levels and the maximum VAR generation or absorption changes linearly with the utility or ac system voltage[9].

A STATCOM has mainly consisted of a voltage source controller and the corresponding shunt-connected transformer. Although it acts as a static part of the rotating synchronous device, its absence of moving parts makes it faster speed than the older dynamic compensators. The basic structure of the STATCOM is shown in Fig.1. 


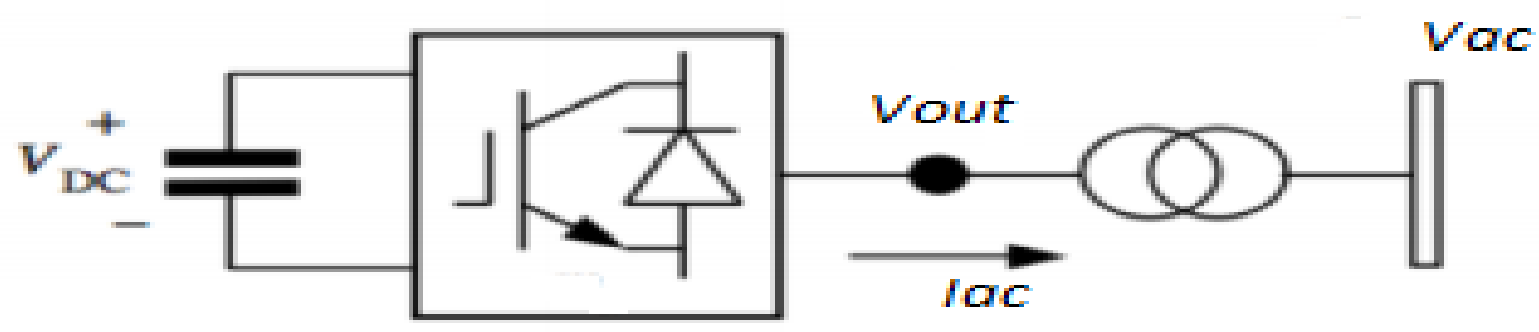

Fig. 1. The STATCOM is A shunt connected device.

\section{PRINCIPLE WORK OF (STATCOM)}

Exchange the reactive power between the STATCOM and the PS can be carrying out by changing the output voltage range $\left(\mathrm{v}_{\text {out }}\right)$ of the three-phase STATCOM inverter, if the output voltage $\left(\mathrm{v}_{\text {out }}\right)$ of the statcom is larger than the $\mathrm{AC}$ power system voltage $\left(\mathrm{v}_{\mathrm{ac}}\right)$, The current flow towards the power system through the transformer's reactor ,the STATCOM generate capacitive reactive power, if the output voltage $\left(\mathrm{v}_{\text {out }}\right)$ of the statcom is smaller than the AC power system voltage $\left(\mathrm{v}_{\mathrm{ac}}\right)$ The current flow towards the statcom. The STATCOM absorbs inductive reactive power from the power system. No power exchange occur if there is equilibrium between the voltages[10].

The exchanged reactive power given by the following relationship[9] :

$$
Q=\frac{V_{a c}\left(V_{a c}-V_{o u t}\right)}{x} \quad \text {......... }
$$

Where :

Q: reactive power.

$\mathrm{V}_{\mathrm{ac}}$ : power system voltages.

$\mathrm{V}_{\text {OUT }}$ : STATCOM voltages.

$X$ : STATCOM Impedance equivalent.

If $\mathrm{Q}(-)$ is negative the STATCOM given reactive power ,if $\mathrm{Q}(+)$ is positive the STATCOM absorb reactive power.

\section{TESTING SYSTEM}

When the power system is subjected to disturbances, it passes through a series of dynamic events such as prefault, fault, and post-fault condition respectively. Under those provisions, the action of the system can be acquired by solving swing-equation. The dynamics of the ith machine of the multi-machine system deserting the damping effect is explained in the following equations

$$
\frac{d \delta_{i}}{d t}=w_{i} \quad \ldots \ldots .2
$$

$$
\begin{aligned}
& M_{i} \frac{d w_{i}}{d t}=p_{m i}-p_{e i}=f_{i}(\delta) \\
& \text { For } i=1,2,3 \ldots \ldots . . . . . \\
& \delta_{i}, \mathrm{w}_{\mathrm{i}} \text { are the rotor angular deviation and angular } \\
& \text { frequency of the } \mathrm{i}^{\text {th }} \text { machine respectively. }
\end{aligned}
$$

$M_{\mathrm{i}}$ is the moment of inertia of the $\mathrm{i}^{\text {th }}$ machine.

$p_{m i}$ is the input mechanical power of the $\mathrm{i}^{\text {th }}$ machine.

$p_{e i}$ is electrical power injected into network by $\mathrm{i}^{\text {th }}$ machine.

A multi-machine IEEE-9 bus was selected for our studies, the system consisting of 9 busbar, 3 generators, 6 transmission lines and 3 loads shown in fig. 2. [12]. The constants for synchronous generators per unit values(p.u) attributed to basis $100 \mathrm{MW}$ in [13].

\section{SIMULATION AND DISCUSSION}

We used software environment MATLAB/simulation power system to model the studied electric power system, Parameters for each component have been entered separately, to form the resource network. A symmetrical three-phase fault was applied in the middle of transmission line 1 . at the moment 1.5 seconds. Considering that the base $100 \mathrm{MVA}$ and the frequency $60 \mathrm{~Hz}$.

The oscillation of the relative rotor angles of generators 2 and 3 was analyzed for the reference generator number 1. For studies transient stability, after determining the CCT of the test system.

\subsection{Apparatus and Procedures}

First, load flow has been studied for the 9-busses system through the phasors unit using MATLAB/SIMULINK, it illustrated in the form of the network studied Fig. 2 and load flow data were tabulated as shown in table 1 . 


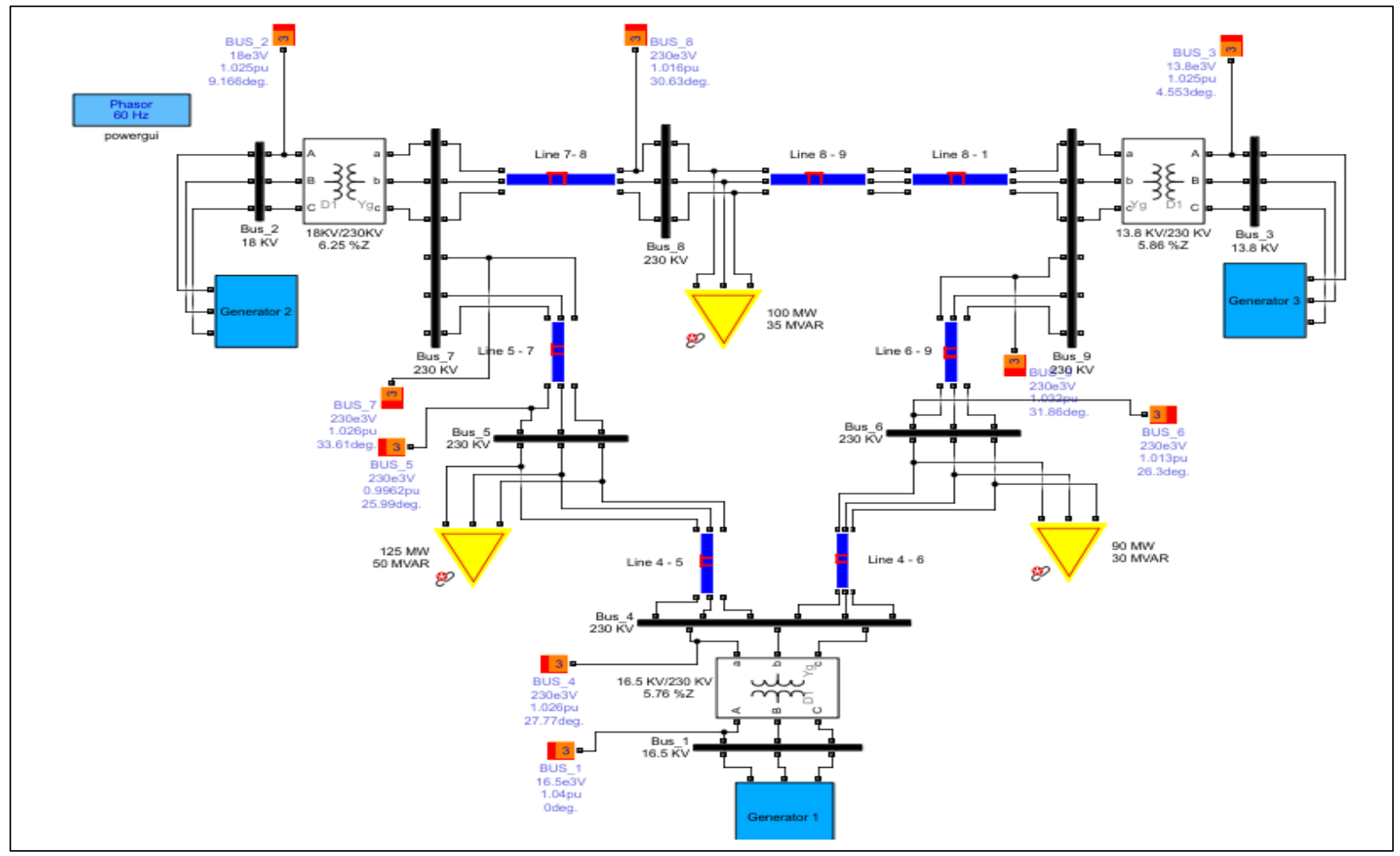

Fig. 2. Modeling the studied network using MATLAB

It can be seen from the table. 1 that:

1-Generator (1) Injected reactive power $+22.3 \mathrm{MVAR}$

2-Generator (2) absorbs reactive power -5.01 MVAR

3-Generator (3) absorbs reactive power -15.10 MVAR

And as the network loads require reactive power 115 MVAR

Table1.

Load flow results
It turns out that there is a deficit in the required reactive power for the network equal:

\section{$-115-5.01-15.1+22.3=-112.81$ MVAR}

Therefore it is necessary to install a $100 \mathrm{MVAR}$ reactive power compensator. We have chosen this capability because it is as close as possible to the required reactive power as a standard available value For this network to cover its required reactive power.

\begin{tabular}{|c|c|c|c|c|c|c|c|c|c|c|}
\hline $\begin{array}{c}\text { Bus } \\
\text { no. }\end{array}$ & $\begin{array}{l}\text { Bus } \\
\text { type }\end{array}$ & $\mathrm{V}$ (base) $\mathrm{kv}$ & Vref(p.u) & $\begin{array}{r}\mathrm{V} \text { (angle) } \\
\text { degree }\end{array}$ & $\operatorname{Pg}(\mathrm{MW})$ & $\mathrm{Q}(\mathrm{MVAR})$ & $\begin{array}{r}v^{-} \\
\text {lf(p.u) }\end{array}$ & $\begin{array}{r}\mathrm{v}- \\
\text { angle(deg) }\end{array}$ & $\begin{array}{r}\text { P-LF } \\
(\mathrm{MW})\end{array}$ & $\begin{array}{r}\text { Q-LF } \\
\text { (MVAR) }\end{array}$ \\
\hline 1 & swing & 16.5 & 1.04 & 0.00 & 150 & 0.00 & 1.04 & 0.00 & 148.93 & 22.3 \\
\hline 2 & PV & 18.00 & 1.025 & 0.00 & 85 & 0.00 & 1.025 & -1.24 & 85.00 & -5.01 \\
\hline 3 & $\mathrm{PV}$ & 13.8 & 1.025 & 0.00 & 85 & 0.00 & 1.025 & 0.33 & 85.00 & -15.10 \\
\hline 4 & - & 230 & 1 & 0.00 & 0.0 & 0.0 & 1.0357 & 28.16 & 0.00 & 0.00 \\
\hline 5 & PQ & 230 & 1 & 0.00 & 125 & 50 & 1.0068 & 24.14 & 125 & 50 \\
\hline 6 & PQ & 230 & 1 & 0.00 & 90 & 30 & 1.021 & 25.31 & 90 & 30 \\
\hline 7 & - & 230 & 1 & 0.00 & 0.0 & 0.0 & 1.0271 & 27.27 & 0.00 & 0.00 \\
\hline 8 & PQ & 230 & 1 & 0.00 & 100 & 35 & 1.0169 & 25.42 & 100 & 35 \\
\hline 9 & - & 230 & 1 & 0.00 & 0.0 & 0.0 & 1.0326 & 28.23 & 0.00 & 0.00 \\
\hline
\end{tabular}


Fig.3. shows the oscillation of the rotor angles of generators 2 and 3 for the reference generator 1 , when symmetric 3 phase fault occurs in the middle of the line 1 at the moment $\mathrm{t}=1.5 \mathrm{sec}$.
Where it is noted that with the damping vibrations of the rotor angles after the first swing (maximum) Gradually, the system has maintained its stability at new working angle approval for fault clearing time $(\mathrm{FCT})=254 \mathrm{~ms}$.

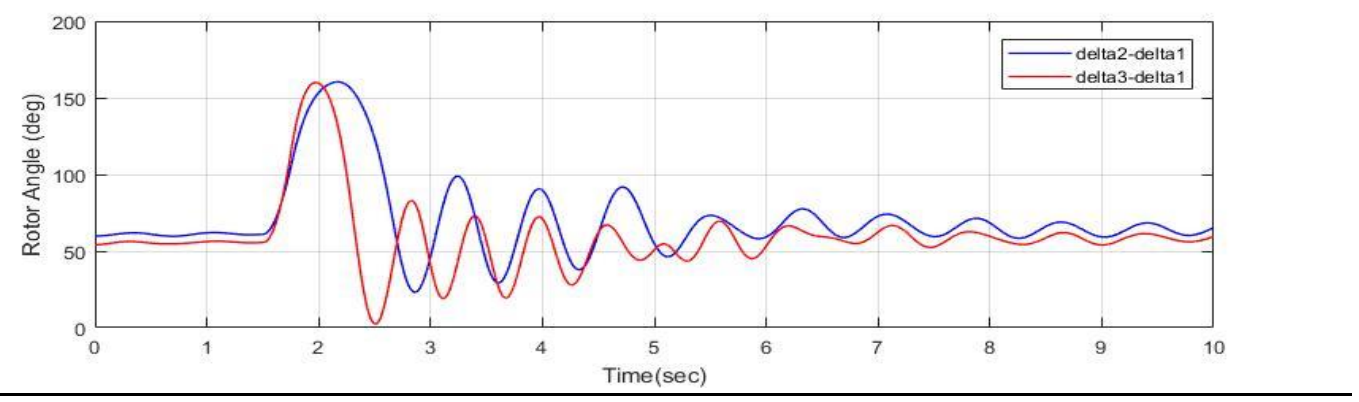

Fig. 3. System response of rotor angle for FCT $=254 \mathrm{~ms}$

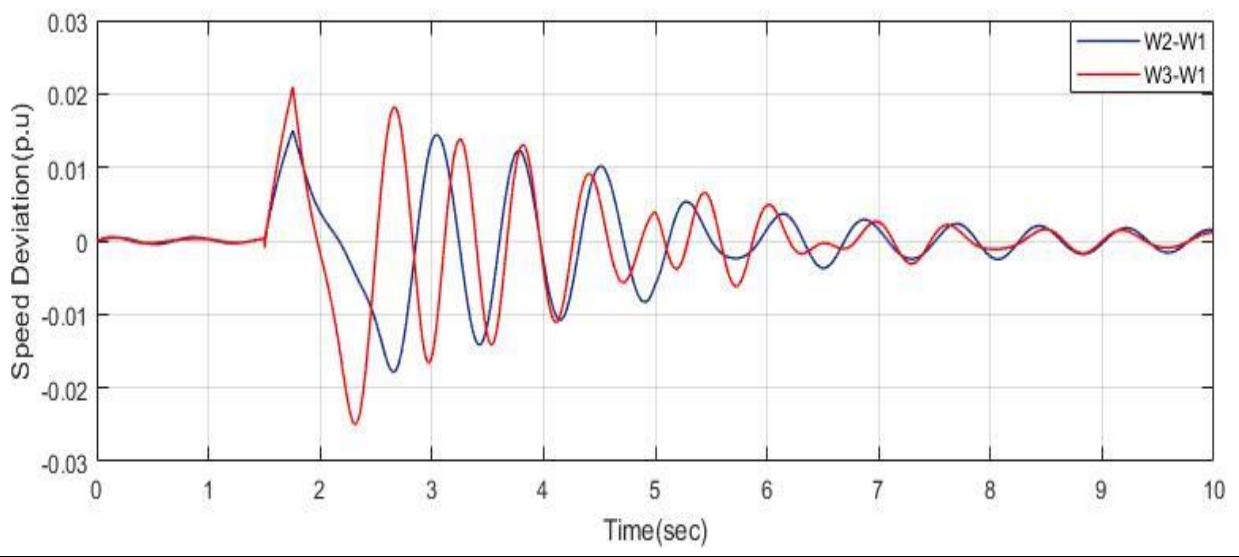

Fig. 4. System response of speed deviation for FCT $=254 \mathrm{~ms}$

In Fig. 4. The relative angular speed of generators 2 and 3 for the reference generator 1 in the critical state of the grid. The w3-w1 signal is more affected by the fault than the w2-w1signal because it is close to the fault site, we notice, However the relative speed of generators 2 and 3 will damped temporarily until reach its synchronous speed, indicating that the system remains stable voltages .

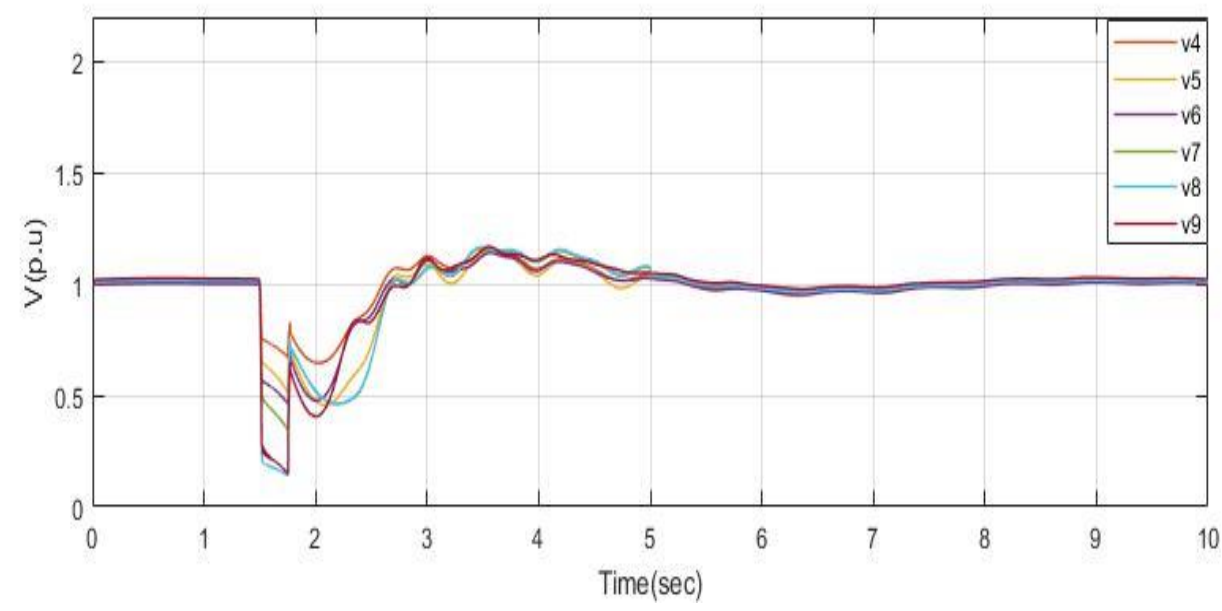

Fig. 5. The voltage buses for FCT $=254 \mathrm{~ms}$ 
Fig.5. shows the relationship between the voltages and time at the bus bar $230 \mathrm{kv}$, Low voltage values are observed after the fault occur at different values depending on the impedance observed from the bus bar. However, this Values return to settle at values close to nominal values. Voltage v8 v9 is more vulnerable(low voltage), due to the proximity of nodes 8 and 9 to the fault location, while v4 lowest affected by the fault due to the distance far between the node and the fault location.

Increasing fault clearing time FCT value to $255 \mathrm{~ms}$ This leads to an increase in the relative rotation angles of very large values, which means that the system has lost its stability.

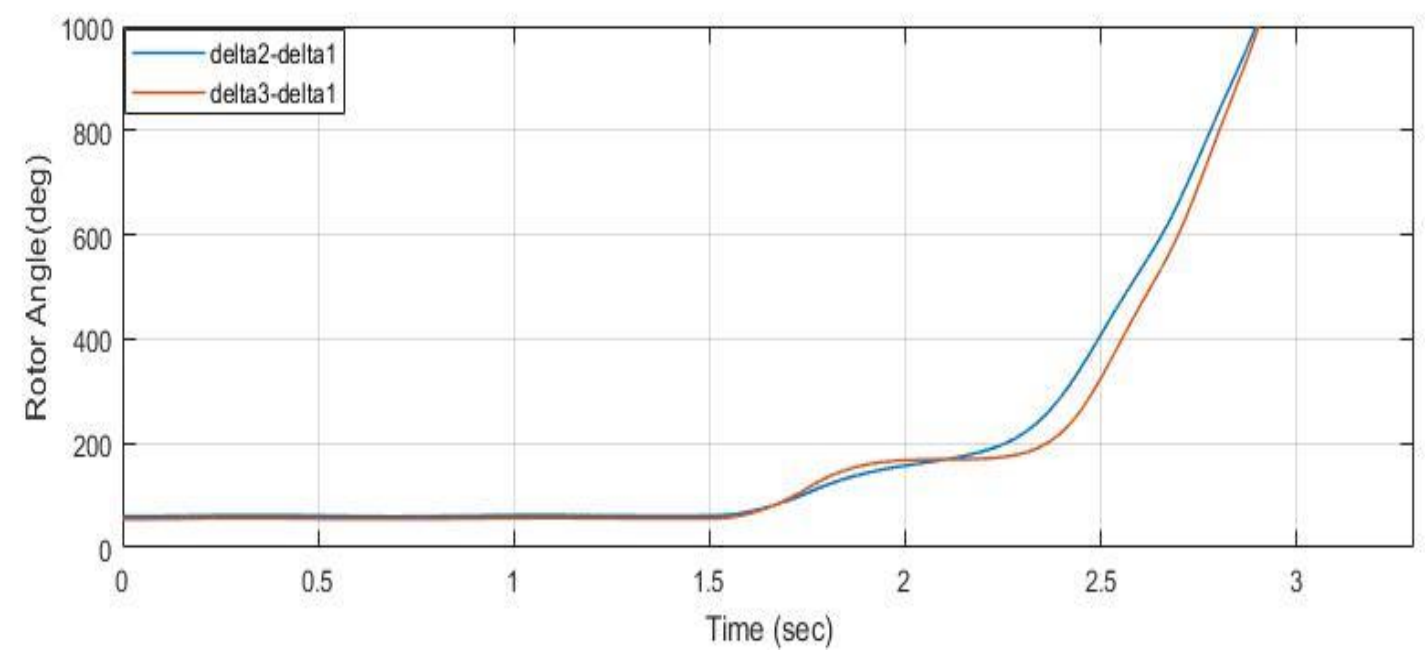

Fig. 6 System response of rotor angle for FCT $=255 \mathrm{~ms}$

Generator continues to accelerate due to the increased duration of the fault period, where the mechanical input power remains constant, In Fig.7., we notice that despite the disappearance of the fault at the time FCT $=255 \mathrm{~ms}$
The rotor speed of generator 2 and 3 continues to increase. The curves show that the system can no longer maintain stability.

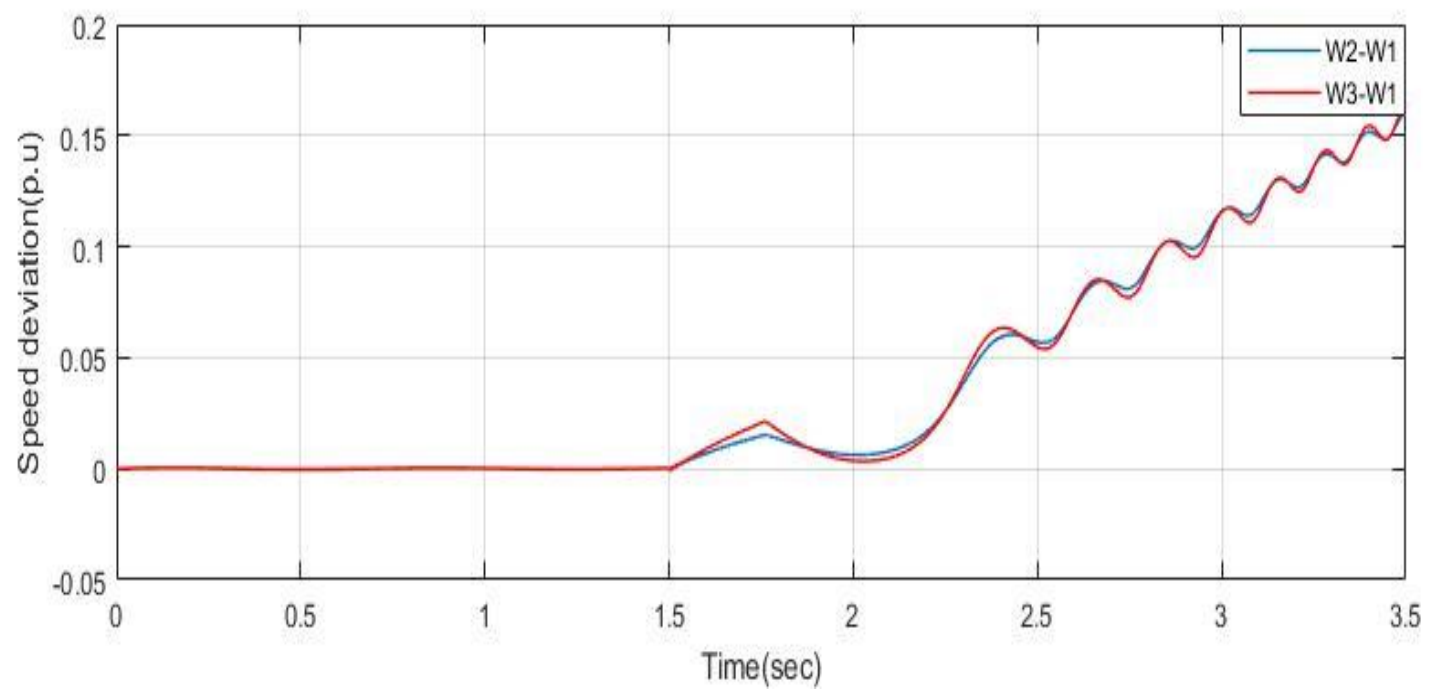

Fig. 7. System response of speed deviation for FCT $=255 \mathrm{~ms}$ 
Fig. 8. shows that there has been a sharp drop in node (8) and (9) near the fault due to an increase in the in the duration of the fault time than the CCT of the studied grid and the studied power system is no longer able to restore the nominal values of the node due to the lack of reactive power.

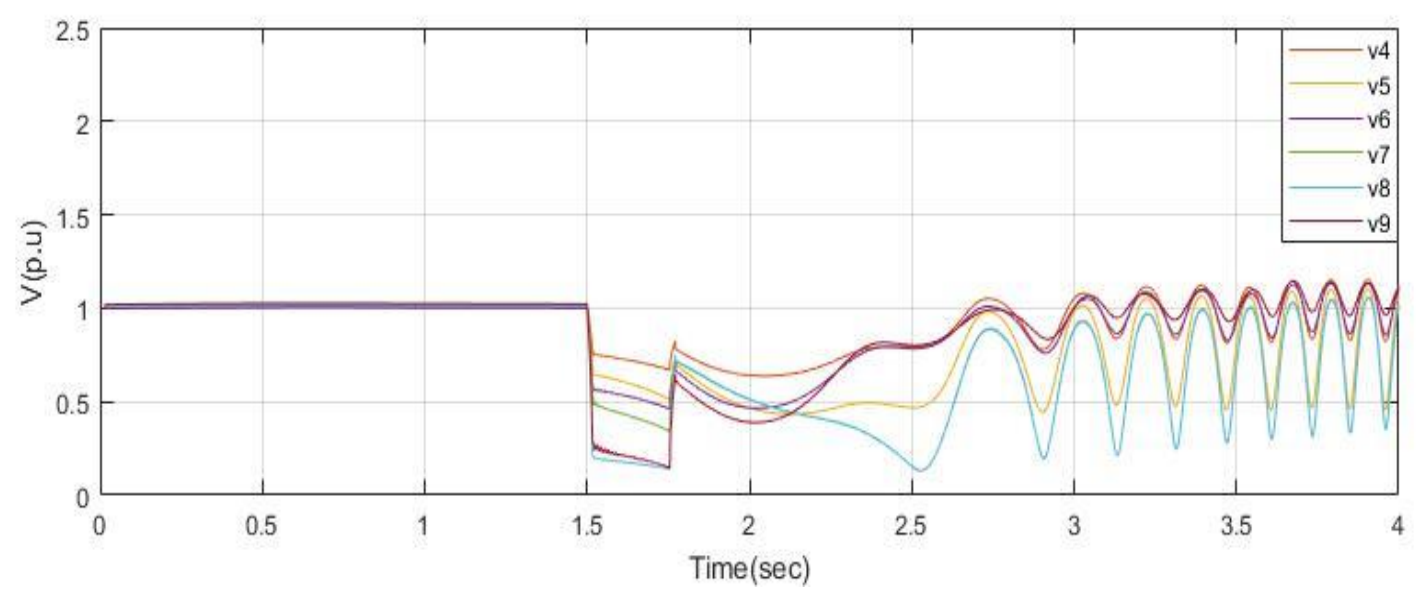

Fig. 8. The voltage buses for $\mathrm{FCT}=255 \mathrm{~ms}$

\subsection{The power system performance with STATCOM}

We will study the performance of the power system studied in two compensating cases ,using one STATCOM and using two STATCOM.

\subsubsection{Grouped STATCOM state}

The status of a grouped compensator means one compensator placed in one place with reactive power required for the electrical system. It will be studied what is the best location to connect the grouped STATCOM compensator to improve CCT. In this case, we connect 100 MVAR STATCOM grouped to all busbars and lines in the studied power system with fault occurs in middle transmission line 1 and calculate the CCT. This is to determine the best location for the 100 MVAR grouped STATCOM compensator, which gives the best CCT.

\section{a. Connecting the grouped STATCOM to the busbars}

We connected the STATCOM on each busbar of the studied power system and study The transient stability In each case, then we determine the CCT corresponding for each STATCOM compensator site. Table 2. shows the CCT for the studied network after connecting the STATCOM to the bus bars When a three-phase fault occurs in the middle of the transmission line 1 at the moment $\mathrm{t}=1.5 \mathrm{msec}$.

\section{Table2.}

The CCT for the studied system after connecting grouped STATCOM

\begin{tabular}{|c|c|c|c|c|c|c|c|c|c|}
\hline Node no. & 1 & 2 & 3 & 4 & 5 & 6 & 7 & 8 & 9 \\
\hline & & & & & & & & & \\
CCT (msec) & 272 & 276 & 279 & 272 & 273 & 274 & 276 & 275 & 279 \\
\hline
\end{tabular}

It shown from the table 2. That the best site to connect the grouped STATCOM with $100 \mathrm{MVAR}$ reactive power in node 9 to improve CCT, this because node 9 near the STATCOM grouped located very close to the 
generator 3, this generator the most vulnerable network generators due to its proximity to the fault site (where it is away from the fault $50 \mathrm{~km}$ ), because the compensator's proximity to the fault site supports the fault point voltages, it reduces the risk of its impact on this generator and other system generators.

\section{b. Connecting the grouped STATCOM on the transmission lines}

In this state, the STATCOM is connected at each line of the grid lines and in many places of the line, ( middle

\section{Table 3.}

The best sites for connecting the grouped STATCOM on the transmission lines.

\begin{tabular}{|c|l|l|l|c|}
\hline \multicolumn{2}{|c|}{ No. Transmission Line } & \multicolumn{2}{|c|}{ Optimal site to connect STATCOM on transmission line } \\
to improve CCT & $\begin{array}{c}\text { CCT in } \\
\text { msec }\end{array}$ \\
\hline 1 & (bus 8- bus 9) & $99.5 \mathrm{~km}$ from node 8 & $0.5 \mathrm{~km}$ from node 9 & 279 \\
\hline $\mathbf{2}$ & (bus 7- bus 8) & $1 \mathrm{~km}$ from node 7 & $99 \mathrm{~km}$ from node 8 & 260 \\
\hline 3 & (bus 6- bus 9) & $80 \mathrm{~km}$ from node 6 & $20 \mathrm{~km}$ from node 9 & 280 \\
\hline 4 & (bus 5- bus 7) & $95 \mathrm{~km}$ from node 5 & $5 \mathrm{~km}$ from node 7 & 279 \\
\hline 5 & (bus 4- bus 5) & $85 \mathrm{~km}$ from node 4 & $15 \mathrm{~km}$ from node 5 & 262 \\
\hline 6 & (bus 4- bus 6) & $90 \mathrm{~km}$ from node 4 & $10 \mathrm{~km}$ from node 4 & 260 \\
\hline
\end{tabular}

Where (99.5 km from node 8, $0.5 \mathrm{~km}$ from node 9) means that the compensator is bound between nodes 8 and $9,99.5 \mathrm{~km}$ from node 8 and $0.5 \mathrm{~km}$ from node 9 .

As shown in Table 3, connecting the grouped STATCOM with a capacity of 100 MVAR on line 3 at $80 \mathrm{~km}$ from node 6 and $20 \mathrm{~km}$ from node 9 is the best location of the power system with its lines and nodes to improve the CCT of the studied network. This is due to its proximity to the third generator and the location of the fault. Therefore, the best value of the CCT with the presence of collected compensation is CCT $=280 \mathrm{msec}$.

\subsubsection{Distributed STATCOM state}

of it - a certain distance from the load node-a certain distance from the node near the source of generation...etc ) to illustrate the best location of the compensator from the transmission lines. To study the site of the compensator, we have experimentally changed the FCT to determine the value of the CCT of the corresponding network for this site. Table 3. shows the best sites for connecting the STATCOM on transmission lines of the studied network in order to improve the CCT.
Based on previous results the CCT $=280 \mathrm{~ms}$, it is the best time for our network of studied and resulting from connecting grouped STATCOM with 100MVAR at line 3, and for Looking at the fig.9. which shows the relative wave of the rotor angles of the 2 and 3 generators, the maximum value of the first oscillation of the rotor angles of the second generator is greater than that of the rotor angles of the third generator corresponding to the same time CCT $=280 \mathrm{msec}$.

When the FCT has increased to the value $281 \mathrm{msec}$ we noticed that the second generator was out of stability however, the third generator remained stable This means that the system as a whole is unstable as shown in Fig. 10.

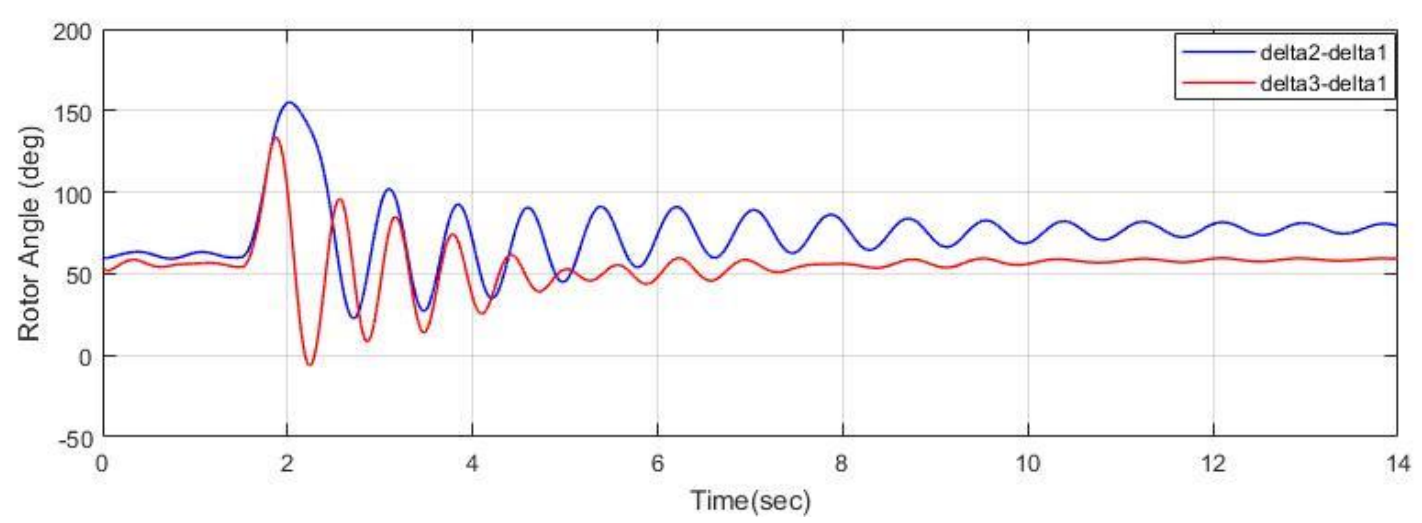

Fig. 9. System response of rotor angle for FCT $=280 \mathrm{~ms}$ 


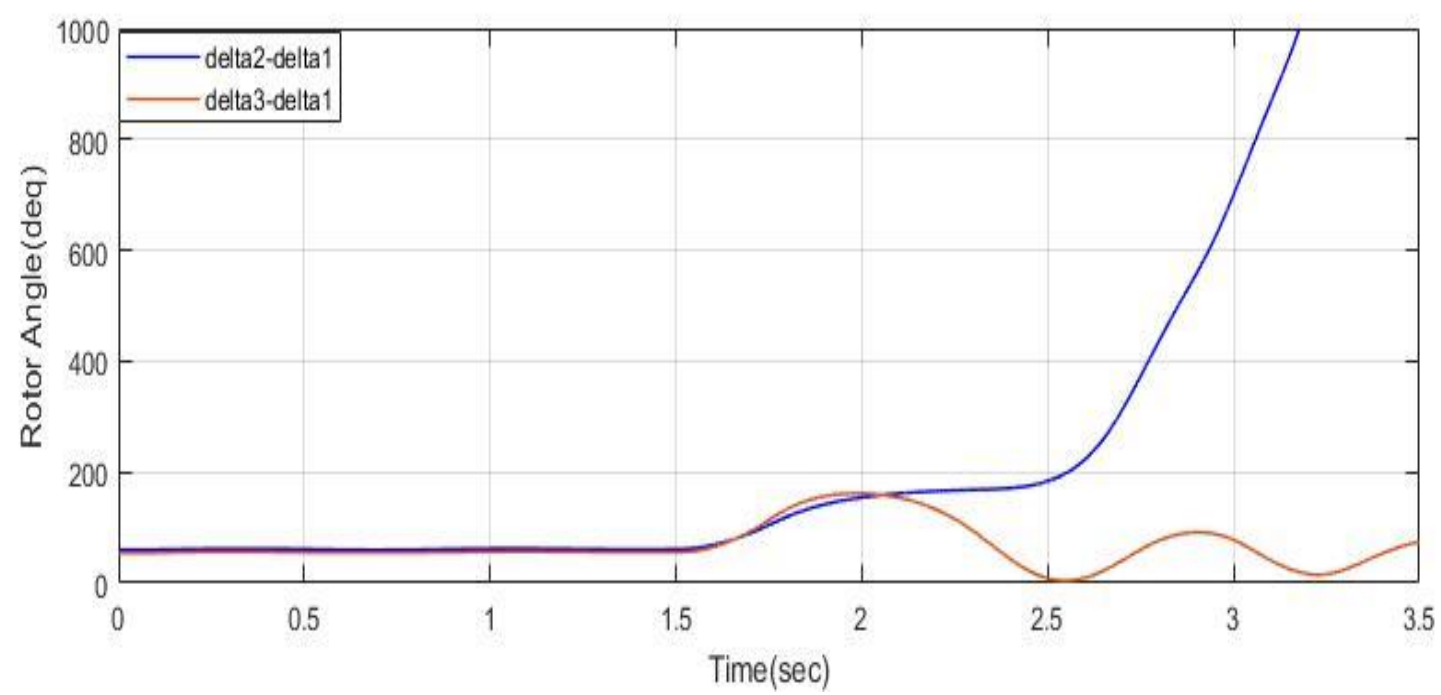

Fig. 10. System response of speed deviation for FCT $=281 \mathrm{~ms}$

This is due to the support of the voltage of the nodes near the third generator by the compensator and thus supports the power of the lines bound with it. As for the second generator, the compensator is far from G2 and the compensator cannot support their voltage node or the nearby ones sufficiently to keep the system stable.

For these reasons, we have separated the grouped compensator and connected two distributed compensators with total capacity 100 MVAR, Where one of them was linked to the best sites that we got from linking grouped STATCOM (ie on line 3 or at node 9). The other was connected to a place close to the generator 2 (at the best locations on lines 2 and 4). So that network nodes voltages are supported by both generators 2 and 3 simultaneously instead of unilaterally in the case of grouped compensators whose impact on the nodes away from its binding site (like nodes 7, 2) was insufficient to keep the system stable at the FCT $=281 \mathrm{msec}$ as shown in Fig. 10.

\section{a. Determine the ability of distributed STATCOM and their optimal location in the network.}

During the study, it was found that the best locations shown in Table 3 are the same when we changed the compensator capacity according to the values $(40,50,60,100)$ MVAR, to improve the CCT. The results showed that the best powers that can be selected for compensators to improve CCT are (50MVAR , 50MVAR) or 60 MVAR For the first compensator which is connected to the (generator 3 ) and 40 MVAR for the second compensator which is connected to the generator 2 .
This is because ( generator 2) provides $163 \%$ of its nominal base MVA power, This makes it the most network generator affected by the risk of fault, While generator 3 offers a power of $0.85 \%$ of the same nominal base MVA, Thus it will be less affected by the risk of fault than the generator 2. but Apply fault in the middle line 1 to $50 \mathrm{~km}$ from the generator 3 and distance $150 \mathrm{~km}$ away from the generator 2 as shown in fig. 2, the impact of the fault risk on generator 3 made it slightly larger than on generator 2. Therefore, the signal's difference of the relative rotor angles to generators 2 and 3 were small as shown in Figure 4, therefore Generator 3 needs more reactive power support than Generator 2 and requires choice (50 MVAR,50MVAR), provided you put 50MVAR at line 3 when best site of the power system is reached, or (40MVAR,60MVAR) so that 60 MVAR from the generator 3 side and 40 MVAR from another side. Table 3 shows the best sites to connect the two compensators with reactive-power equal 100 MVAR.

Table 4. shows that the best two cases reached to improve the CCT of the studied network are the first case with two compensators (50MVAR,50MVAR) where the CCT value was $312 \mathrm{msec}$, this is when placing the first compensator in the best compensation site on the network studied mean line 3 (It is itself the best site whatever the compensator power) and the second compensator is close to the generator 2 in the best compensation position at line 4 , and the second case with two compensators, 60MVAR connected close to generator 2, 40MVAR compensator located on the generator 3 side, the first compensator was linked to the bus 9 and the second compensator at his best position on line 4 . The value of the CCT was $312 \mathrm{msec}$ too.

Table 4. 
Best sites linking two STATCOMs, total their capacity 100MVAR

\begin{tabular}{|c|c|c|c|}
\hline STATCOM Capacity & $\begin{array}{c}\text { Site linked first } \\
\text { STATCOM }\end{array}$ & $\begin{array}{c}\text { Site linked second } \\
\text { STATCOM }\end{array}$ & CCT ms \\
\hline \multirow{13}{*}{$\begin{array}{l}50 \text { MVAR for first } \\
\text { STATCOM } \\
\text { And } \\
\text { 50 MVAR for second } \\
\text { STATCOM }\end{array}$} & Line 3 & Line 4 & \multirow[b]{2}{*}{312} \\
\hline & $\begin{array}{l}80 \mathrm{~km} \text { from node } 6 \\
20 \mathrm{~km} \text { from node } 9\end{array}$ & $\begin{array}{l}95 \mathrm{~km} \text { from node } 5 \\
5 \mathrm{~km} \text { from node } 7\end{array}$ & \\
\hline & Line 3 & Line 2 & \multirow[b]{2}{*}{309} \\
\hline & $\begin{array}{l}80 \mathrm{~km} \text { from node } 6 \\
20 \mathrm{~km} \text { from node } 9\end{array}$ & $\begin{array}{c}1 \mathrm{~km} \text { from node } 7 \\
99 \mathrm{~km} \text { from node } 8\end{array}$ & \\
\hline & Line 1 & Line 4 & \multirow[b]{2}{*}{294} \\
\hline & $\begin{array}{l}99.5 \mathrm{~km} \text { from node } 8 \\
0.5 \mathrm{~km} \text { from node } 9\end{array}$ & $\begin{array}{l}95 \mathrm{~km} \text { from node } 5 \\
5 \mathrm{~km} \text { from node } 7\end{array}$ & \\
\hline & Line 3 & \multirow[b]{2}{*}{ At node 7} & \multirow[b]{2}{*}{282} \\
\hline & $\begin{array}{l}80 \mathrm{~km} \text { from node } 6 \\
20 \mathrm{~km} \text { from node } 9 \\
\end{array}$ & & \\
\hline & At node 9 & At node 7 & 282 \\
\hline & \multirow[b]{2}{*}{ At node 9} & Line 4 & \multirow[b]{2}{*}{310} \\
\hline & & $\begin{array}{l}95 \mathrm{~km} \text { from node } 5 \\
5 \mathrm{~km} \text { from node } 7\end{array}$ & \\
\hline & \multirow[b]{2}{*}{ At node 9} & Line 2 & \multirow[b]{2}{*}{300} \\
\hline & & $\begin{array}{c}1 \mathrm{~km} \text { from node } 7 \\
99 \mathrm{~km} \text { from node } 8\end{array}$ & \\
\hline \multirow{13}{*}{$\begin{array}{l}60 \text { MVAR for first } \\
\text { STATCOM } \\
\text { And } \\
40 \text { MVAR for second } \\
\text { STATCOM }\end{array}$} & Line 3 & Line 4 & \multirow[b]{2}{*}{310} \\
\hline & $\begin{array}{l}80 \mathrm{~km} \text { from node } 6 \\
20 \mathrm{~km} \text { from node } 9\end{array}$ & $\begin{array}{l}95 \mathrm{~km} \text { from node } 5 \\
5 \mathrm{~km} \text { from node } 7\end{array}$ & \\
\hline & Line 3 & Line 2 & \multirow[b]{2}{*}{310} \\
\hline & $\begin{array}{l}80 \mathrm{~km} \text { from node } 6 \\
20 \mathrm{~km} \text { from node } 9\end{array}$ & $\begin{array}{c}1 \mathrm{~km} \text { from node } 7 \\
99 \mathrm{~km} \text { from node } 8\end{array}$ & \\
\hline & Line 1 & Line 4 & \multirow[b]{2}{*}{295} \\
\hline & $\begin{array}{c}99.5 \mathrm{~km} \text { from node } 8 \\
0.5 \mathrm{~km} \text { from node } 9\end{array}$ & $\begin{array}{l}95 \mathrm{~km} \text { from node } 5 \\
5 \mathrm{~km} \text { from node } 7 \\
\end{array}$ & \\
\hline & Line 3 & \multirow[b]{2}{*}{ At node 7} & \multirow[b]{2}{*}{282} \\
\hline & $\begin{array}{l}80 \mathrm{~km} \text { from node } 6 \\
20 \mathrm{~km} \text { from node } 9\end{array}$ & & \\
\hline & At node 9 & At node 7 & 283 \\
\hline & \multirow[b]{2}{*}{ At node 9} & Line 4 & \multirow[b]{2}{*}{312} \\
\hline & & $\begin{array}{l}95 \mathrm{~km} \text { from node } 5 \\
5 \mathrm{~km} \text { from node } 7\end{array}$ & \\
\hline & \multirow[b]{2}{*}{ At node 9} & Line 2 & \multirow[b]{2}{*}{311} \\
\hline & & $\begin{array}{c}1 \mathrm{~km} \text { from node } 7 \\
99 \mathrm{~km} \text { from node } 8\end{array}$ & \\
\hline
\end{tabular}

Fig.11. shows a comparison between the oscillation curves of the second generator at CCT $=279 \mathrm{msec}$, (this is the CCT for network if the $100 \mathrm{MVAR}$ compensator is connected to node 9), before and after connecting to STATCOM (100 MVAR) at the best sites that we obtained in the study, which shows the following:

The curve number (3) in Fig. 12 indicates that the system is stable at the best site to connect the compensator from the system node, which is on node 9 at the time CCT $=279$ msec. Where the system was out of stability before this time (curve number 1) as we were shown in the study without compensation.
While it has been noticed through the curve (2) that the first oscillation has improved its suppression when connecting the compensator at the best location of the transmission lines of the studied network on line 3 ( 20 $\mathrm{km}$ from node 9)

The curves (4) and (5) also show the importance of the division of the reactive power required for a network studied between two compensators at the best-connected sites that resulted, suppress the first oscillation amplitude of the rotor angles of the generator 2 as compared to its counterparts in case of compensation 
reactive power required by the qrouped compensator (curve 2\&3).
As a result, CCT of the studied network improves in the case of distributed compensators better than the grouped compensator.

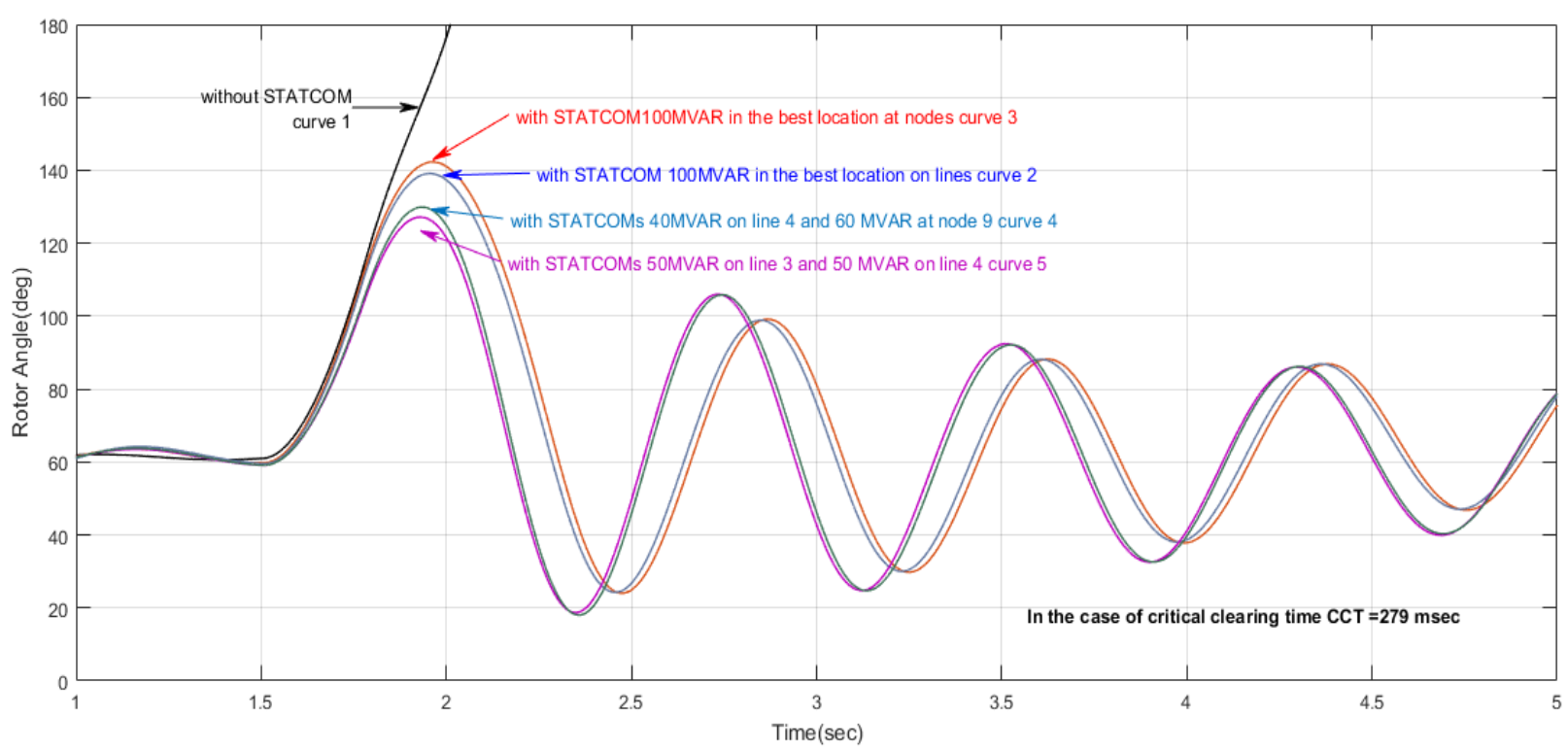

Fig .11. Swing curves for generator 2 for many cases in best location at CCT $=279 \mathrm{msec}$

\section{CONCLUSIONS}

This study investigated the possibility of improving CCT by the selection of the best site connection STATCOM. This is when the symmetrical three-phase fault occurs in the middle line 1 for the studied network. It has been shown that improve the CCT of the studied network in the presence of compensator grouped or distributed and thus improve its transient stability. The best CCT value was when using grouped STATCOM and at the best location of the studied network is $\mathrm{CCT}=279 \mathrm{~ms}$, i.e increased $10 \%$ of CCT before compensation. While the connection of two STATCOM distributed and reactive power that has been selected and

\section{REFERENCES}

[1] D.Murali, Dr.Rajaram And N.peka," Comparison of FACTS Devices for Power System Stability Enhancement",International Journal of Computer Applications (0975-8887) Volume 9-No.8,October 2010 .

[2] Alok kumar mohanty and amar kumar barik " Power System Stability Improvement Using FACTS Devices ", International Journal of Modern in the best locations of the network studied to cover its need for compensation instead of one compensator (grouped STATCOM) with the same reactive power required was very effective in improving CCT of the studied network, in this case, is stigmatized into time $\mathrm{CCT}=312 \mathrm{msec}$, increased $12.3 \%$ of CCT before compensation, this is because the connection of compensators close to the network generators has resulted in supporting voltages and improving the transported power on the transmission lines, thus supporting their transit stability better than when using grouped STATCOM.

Engineering Research (IJMER) Vol. 1No.2,August 2019.

[3] Ishant Shrivastava And Hitesh Kumar Lade ," Review on Stability Mid-point of Transmission Line using STATCOM ", International Journal of Innovative Research in Computer and Communication Engineering ,Vol.5-No.1,January 2017. 
[4] P. Kumkratug, "Critical Clearing Time Assessment of Power System Equipped with a Static Synchronous Compensator," in Proc. Second UKSIM European Symposium on Computer Modeling and Simulation, Liverpool, UK., Sept. 2008, pp. 364-369.

[5] W. Chang, and C. Hsu, "Transient stability enhancement evaluation of cogeneration system by using FACTS elements," in Proc. IEEE Ninth International Conference on Power Electronics and Drive Systems, Singapore, Dec. 2011, pp. 847854.

[6] D. Singla, and P. R. Sharma, "Placement of STATCOM and series capacitor based on CCT assessment for transient stability enhancement," in Proc. IEEE 5th India International Conference on Power Electronics, Delhi, India, Dec. 2012, pp. 16.

[7] K. R. Padiyar, "Facts Controllers In Power Transmission And Distribution",India,2007.

[8] Ali M. Eltamaly, Amer Nasr A. Elghaffar, Yehia Sayed and Abou-Hashema M. El-Sayed," Enhancement of Power System Quality Using Static Synchronous Compensation (STATCOM)", International Journal of Mechatronics', Electrical And computer Technology (IJMECT),Vol.8No.30,October 2018.

[9] Mohammed Y. Suliman ," Voltage profile Improvement Using Static Synchronous Compensator STATCOM", International Journal of Advanced Engineering, Management and Science (IJAEMS),Vol.2-No.5,May 2016.

[10] Sandeep Kumar, Dr. Deependra Singh, Dr. K. S. Verma ," Stability Improvement of Multi-Machine Power System Network using STATCOM \& UPFC ", International Journal for Research in Applied Science and Engineering Technology (IJRASET), Vol.7,October 2019.

[11] B.K.Saha Roy, A.K.Pradhan and A.K.Sinha," Fuzzy Logic based Fast Critical Clearing Time Assessment", 16th national power systems conference, 15th-17th december, 2010.
[12] Mohd. Ilyas and Hashim Farooq Makhdoomi, " Steady State Operation And Enhancement Of Transient Stability In Hydel Power Plant Using Statcom ", International Journal Of Modern Engineering Research (IJMER),Vol.4-No.5, May 2014.

[13] Mohammed Ahsan Adib Murad," Phasor TimeDomain Power System Modeling and Simulation using the Standardized Modelica Language Conventional and Power Electronic-Based Devices", stockholm Enhancement,sweden,2015. 